\title{
Revisiting Emergency Food Reserve Policy and Practice under Disaster and Extreme Climate Events
}

\author{
Jonatan A. Lassa ${ }^{1} \cdot$ Paul Teng ${ }^{2} \cdot$ Mely Caballero-Anthony ${ }^{3} \cdot$ Maxim Shrestha $^{3}$
}

Published online: 6 December 2018

(C) The Author(s) 2018

\begin{abstract}
All food systems will continue to be affected by disasters and extreme climate events. Triggered by recent food crises around the world and climate change concerns, some governments have been trying to develop more robust and resilient food systems. One of the oldest options for many governments is to stockpile emergency food reserves for the purpose of food security and disaster preparedness. In the aftermath of the world food price crises in 2007-2008 and 2011, some governments in Asia have been maintaining emergency food reserves to ensure greater supply and price stability. Disasters and extreme climate events help governments to justify emergency food reserves. This research examined emergency food reserve policies in Indonesia, the Philippines, and Malaysia. Emergency food reserves emerged as a practice where the shared objectives of development, disaster risk reduction, and climate change adaptation have been demonstrated by governments. The findings suggest that most governments maintain the strong view that adequate emergency food reserves can buffer national food price shocks and shocks from disasters and climate change, and soften disruptions in trade due to export bans during times of disasters and climate emergencies.
\end{abstract}

Jonatan A. Lassa

jonatan.lassa@cdu.edu.au

1 Emergency and Disaster Management Studies, Charles Darwin University, Darwin, NT 0909, Australia

2 Natural Sciences and Science Education, National Institute of Education, Singapore 637616, Singapore

3 Centre for Non-Traditional Security Studies, S. Rajaratnam School of International Studies (RSIS), Nanyang Technological University, Singapore 639798, Singapore
Keywords Climate change adaptation · Disaster preparedness - Emergency food reserves - Food security $\cdot$ Food stockpiling $\cdot$ Southeast Asia

\section{Introduction}

The issue of emergency food reserves (EFR) or emergency food stockpiles (EFS) is an inherently contradictory concept. On the positive side, many governments have used this approach as a policy option for pursuing objectives such as food security, disaster preparedness, and famine early warning systems. Recent examples can be found in the Middle East and North Africa (Wright and Cafiero 2011) as well as in South Asia, East Asia, and Southeast Asia (Briones et al. 2012; Caballero-Anthony et al. 2015). On the negative side, EFR/EFS at a large scale might not be efficient (Timmer 1975, 2010) because they can distort food prices and markets (Bigman and Reutlinger 1979; Brennan 2003) and, therefore, are subject to World Trade Organization (WTO) regulations (Lassa and Shrestha 2014; Nakuja and Kerr 2018a, b).

Emergency food reserve/emergency food stockpile policies have been part of food security and disaster preparedness narratives. They are considered an alternative to trade-based policies for food security (Porter 1950; Timmer 2010; Nakuja and Kerr 2018b) that are often affected by extreme climate events and natural hazards. The EFR/ EFS approach has been prescribed by many governments as a form of contingency planning and risk management strategy for unstable periods during droughts, catastrophes, wars, and conflicts. Governments have, at different points in time, usually held some form of emergency food reserves or stocks of key staple commodities (Porter 1950; Nakuja and Kerr 2018b). 
Under global climate change scenarios, food security is at risk and volatile (Porter et al. 2014). The expected increase in climate extremes has generated anticipatory actions from governments, including a new push for EFR policy adoption. Triggered by recent disasters and climate change concerns, some governments have been trying to develop more robust and resilient food systems (Fan and Brzeska 2014; Porter et al. 2014). For many countries in Asia, this means the renewed adoption of EFR. Unfortunately, we argue that this is not well understood in climate change adaptation studies as well as contemporary disaster studies.

The Association of Southeast Asian Nations (ASEAN) first initiated a Food Security Reserve Agreement in 1979, with the purpose of meeting emergency requirements (ASEAN 1979). Policymakers have been aware of the susceptibility of the region to natural hazards and the possibility of food shortages. But it took 30 years, until soon after the world food crisis in 2007-2008 (Hadley and Fan 2010), for the association plus three additional East Asian nations (China, Japan, South Korea) to establish the ASEAN Plus Three Emergency Rice Reserve (APTERR) in 2009, as a mechanism to address potential food shortages in the region in the light of climate and market uncertainties. The final formal agreement was signed in October 2011 in Jakarta (APTERR 2017).

The Association of Southeast Asian Nations also established the ASEAN Food Security Information System (AFSIS) that functions as a central information repository for five commodities-rice, maize, soybeans, sugar, and cassava. AFSIS not only monitors and analyzes production, import, export, inventory stock, price, food security ratio, and self-sufficiency ratio for these commodities but also provides data on losses from both floods and droughts in every member state (Lassa et al. 2016). In theory, AFSIS serves as an early warning mechanism for ASEAN to trigger the activation of APTERR's response mechanism (Saengbangka 2014, personal interview; AFSIS 2017).

This article argues that EFR can function as a means of disaster risk reduction, including climate change adaptation, and aims to understand why governments in Asia are readopting emergency food reserves as national policies, with a focus on Indonesia, the Philippines, and Malaysia. We also explore how disasters and climate change strengthen or weaken government narratives in support of emergency food reserves.

\section{Literature Review}

Establishing emergency food reserves or emergency food stockpiles can be defined as the process of holding back a certain amount of a food commodity from the current production/procurement year for use in the future, anticipating shocks from droughts and other climate-related calamities (Gardner 1979; Caballero-Anthony et al. 2015). This policy anticipates future uncertainties in the market as well as on farms. Because future climate is very likely to be more uncertain, it is often difficult to specify the most optimal food stock quantity to be held at government warehouses. As a result, governments are often trapped in either risk-averse or risk-taking behavior. The former suggests a more ambitious food reserve but it may involve higher cost and investment. The latter may imply a more efficient investment with some risk involved because the market does not always perfectly provide the needed quantity at all times, especially in developing countries.

During the Cold War period, the New York State Civil Defense in the 1950s often prescribed 4-day rations of home food reserves for adults and children. During this period some local governments in the United States even prescribed a detailed list of household food stuffs ranging from types of fruits, milk, cereals, and canned food, among others (Federal Civil Defense Administrator 1952). After the first Green Revolution and the end of the Cold War, international trade proved to be more sufficient than anticipated in guaranteeing a steady supply of food at a lower cost across the world. As a result, the EFR narrative shifted and decreased in importance. Since then maintaining food stockpiles has been equated with inefficient practice, monetary losses related to food spoilage, loss and wastage of food, and deemed distortionary to global trade and markets (Bigman and Reutlinger 1979).

Responding to the global food crisis due to climate uncertainty related to El-Nino that triggered famines in many parts of the world in the early 1970s (Sen 1981), some of the participants of the first World Food Conference in 1974 nonetheless questioned whether an international emergency food stock was necessary. Hawkes (1974) showed how top food exporters of the time, such as the United States and Canada, had a strong influence on shaping the food stock debate. Both countries were interested in public food stocks "with some element of international coordination" (Hawkes 1974, p. 907). In their view, large EFR and food stockpiles could depress farm prices. The two countries also opposed the idea of having a relatively small emergency reserve of 500,000 tons, stored somewhere near potential disaster areas to provide global rapid relief. Canada's delegation argued that "such a stock would only add to costs for storage and turnover, and would not speed relief work" (Hawkes 1974, p. 907) and the United States delegation argued that "there was no reason to believe that earmarking of stocks would help" (Hawkes 1974, p. 907).While some countries continued to maintain national food stocks of important commodities, the overall trend shifted towards trade-based policies and 
international trade to meet domestic food supply deficits (Bigman and Reutlinger 1979). This led most countries to gradually reduce public food stockpiles and stockpiling practices from the 1970s onwards (Massell 1969), including food stockpiles for emergency preparedness objectives (AFSIS 2017; APTERR 2017).

Most countries in Asia have a history of emergency food stocks and public stockpiling of food, particularly rice and other staples (Timmer 1975, 2010). Some of these practices can be traced back to colonial times, while some were implemented after independence to address certain challenges and needs in the domestic food economy ( $\mathrm{Vu} 2003$ ). However, in keeping with global trends of neoliberalism and attendant structural changes, food programs in Asia were also cut back and reduced in scope as part of the liberalization and reform processes that swept the region in the 1980s (Orford 2015). It was also during this period that food self-sufficiency policies (of which stockpiling programs are an important aspect) were frowned upon and pushed aside in favor of more trade-based policies.

There is always some degree of price volatility in the global food market. Many governments, especially those dependent on imports, are continuously concerned with food price volatility and its unpredictability. The food price crisis of 2007-2008 serves as a recent example when suddenly rising prices and volatility saw many people, especially in developing countries, priced out of the market and driven towards hunger (Dawe and Slayton 2010).

The food price crisis of 2007-2008 was an unexpected shock after almost 35 years of relatively stable international food markets (Timmer 2010). It was partially due to this relative stability that many governments around the world became convinced of retiring or putting an end to their public food stockpiling programs. However, following India's and Vietnam's rice and grain export bans in 2007-2008 (Dawe and Slayton 2010; Saini and Gulati 2016), and Russia's wheat export ban in 2010, there was a resurgence in adopting food stockpiling policies across the globe (Welton 2011).

These episodes exposed systemic vulnerabilities of the global food markets for most net-food importing and lower-income countries. Despite having safely relied on international markets to provide food through trade-based policies for decades, it was precisely during a crisis that these countries found markets closing on them. Many major exporters of staples like rice closed their borders by enforcing export bans, which only exacerbated the panic and deepened the crisis (Timmer 2010).

Maintaining food stockpiles has been viewed as a response to international trade uncertainties and volatility (Gilbert 2011). The 2007-2008 crisis was the result of complex and interrelated reasons and since then, there is growing evidence that countries-particularly in Asia and
Africa-are reestablishing or revisiting food stockpiling policy options in order to guarantee food security for their citizens. This trend has been more visible (and popular) in net-food importing and developing countries (World Bank 2012). In the case of thinly-traded commodities such as rice, the decision to adopt food stockpiling policies is likely to result in less stock available globally for export, thus potentially leading to limited supply and sustained higher prices (Timmer 2010). Regardless of the triggers of EFR policy, there are different categories of food reserve to be considered, as explained in Sects. 2.1-2.5.

\subsection{Emergency/Humanitarian Food Stocks}

These are stocks which are maintained to protect access to food, especially for vulnerable groups, in the event of a food shortage during emergencies. Release of such food stocks occurs in the event of any type of emergency, or as part of bigger post-disaster safety nets, as deemed necessary by governments. Maintaining reserves for emergencies and/or unforeseen disasters is another aspect that makes food stockpiling a particularly attractive proposition (Caballero-Anthony et al. 2015).

Till today, emergency food stockpiling anticipating local disaster is still a routine disaster preparedness practice in Japan where food stocks are monitored on a regular basis (Caballero-Anthony et al. 2015). To ensure that food and nutrition supplies are secured at both municipal and household levels, the Japanese government has prescribed the stockpiling of 2 weeks' worth of food rations (Nozue et al. 2014).

\subsection{Stocks for Food Security and Price Stabilization}

This type of food stockpile has an embedded welfare objective as it functions as a buffer. Food security stocks are used to ensure stability in the availability and price of food (Gardner 1979; von Braun 2009; Dorosh 2009). Such stockpiles are usually used by governments to control domestic supply and domestic prices of food. The theoretical foundation of such stocks is that governments procure food from farmers and/or markets on the cheap and release stocks when market prices move above what are deemed acceptable levels in terms of affordability (Gardner 1979). This concept is based on a formal definition of food security. The 1996 World Food Summit adopted the concept of stability in the definition of food security with the inclusion of "at all times" to be integrated with the three dimensions of food security - physical availability of food, economic and physical access to food, and utilization (a nutritional concern) of food. Stability has often been referred to as the fourth dimension (FAO 2003). Disasters and extreme climate events can challenge the stability of 
food availability, ranging from farms to supply chains. The practice of food stockpiling has often been used partly to secure stability in terms of availability and access to food.

\subsection{Safety Net Food Stocks}

Safety net stocks are targeted at lower-income segments of society. Such food stocks are often sold at highly subsidized prices (Hossain and Deb 2010). This type of food stock is sometimes maintained and stored together with stocks for food security purposes. However, unlike stocks for food security, safety net stocks are targeted at certain groups or beneficiaries as classified by governments and based on defined poverty lines, as seen in countries like India and Indonesia (Caballero-Anthony et al. 2015). Such stocks are generally intended to improve food availability and access for populations who suffer from chronic food insecurity.

\subsection{Food Stocks for Trade}

Harvesting and post-harvesting depend very much on climate variability and change. Climate matters to food production, from planting to harvest to the post-harvest stage. Farmers in Vietnam and Thailand often use very simple drying and storing technology at household and district levels. Rice, for example, is processed by threshing and drying, and safe storage should occur within $24 \mathrm{~h}$. Without good processing technology for drying and storage, farmers often experience grain loss, both in terms of quantity and quality. In general, aggregated losses from the rice harvest and post-harvest stages are about $30 \%$ of the yield (Brolley 2015; Teng et al. 2016). These problems have often triggered governments to develop more resilient storing technology to ensure good stock for trade. This type of public stock is often seen as an anomaly because it is held by major exporting countries that have little urgency in terms of needing to ensure food availability for their people. The purpose of such stocks is essentially to mitigate losses as well as guarantee minimum profit margins for farmers and export stability.

\subsection{International/Multilateral Food Stockpiles: Regional Food Reserves}

Probably the most cited and well-known example of a regional food reserve mechanism is the ASEAN Plus Three Emergency Rice Reserve (APTERR). Comprising the 10 ASEAN member states plus China, Japan, and South Korea, the reserve was set up to help the region stabilize rice (the region's staple food crop) supplies during emergencies. In 2014, APTERR had 787,000 tons of pledged rice at its disposal (Jeamchareon 2014, personal interview). Other examples of regional food reserves include the South Asian Association for Regional Cooperation (SAARC) Food Bank in South Asia and the Economic Community of West African States (ECOWAS) regional humanitarian food reserve.

\section{Research Methods, Framework, and Scope}

This research combined primary and secondary data collection (Table 1). The primary data collection consisted of field interviews and observations in ASEAN countries, especially Indonesia, the Philippines, Malaysia, Thailand, and Vietnam and occurred from September 2014 to March 2015.

The authors conducted 12 interviews with experts from (1) multilateral organizations and institutions-for example, the Food and Agriculture Organization (FAO), the World Food Programme (WFP), and ASEAN; (2) food and agriculture research institutes-for example, the International Rice Research Institute (IRRI); and (3) officials,

Table 1 Research methods for assessing food stockpiling policies in Indonesia, the Philippines, and Malaysia

\begin{tabular}{|c|c|c|c|c|}
\hline \multirow[t]{2}{*}{ Areas of inquiry } & \multicolumn{2}{|l|}{ Sources of information } & \multicolumn{2}{|l|}{ Methods } \\
\hline & Primary & Secondary & Quantitative & Qualitative \\
\hline Stockpiling statistics (past and present) & $\begin{array}{l}\text { Fieldwork: semistructured } \\
\text { interviews }\end{array}$ & $\begin{array}{l}\text { Secondary } \\
\text { data }\end{array}$ & $\mathrm{X}$ & \\
\hline Commodities being stockpiled & & & $\mathrm{X}$ & \\
\hline Perception of policymakers on the rationale for stockpiling & $\begin{array}{l}\text { Fieldwork: semistructured } \\
\text { interviews }\end{array}$ & $\begin{array}{l}\text { Secondary } \\
\text { data } \\
\text { Media reports }\end{array}$ & $X$ & $\mathrm{X}$ \\
\hline External and internal implications of stockpiling & Fieldwork: expert interviews & $\begin{array}{l}\text { Secondary } \\
\text { data }\end{array}$ & & $\mathrm{X}$ \\
\hline Stockpiling infrastructure & Semistructured interviews & & & $\mathrm{X}$ \\
\hline
\end{tabular}


authorities, and institutions representing national governments-for example, the Indonesian Bureau of Logistics (BULOG) and the National Food Authority and Department of Agriculture of the Philippines.

While extrapolated from a much larger research on public stockpiling of food in Asia (including China, India, and Japan), for the purpose of this article, we present the cases from three ASEAN countries, that is Indonesia, the Philippines, and Malaysia. The findings from Vietnam, Thailand, and India will be discussed in a separate article. The selected countries have been prone to floods and other natural hazards and have had a history of public stockpiling of food that has seen its ups and downs. These countries are also the largest importers of rice (their main staple) and were impacted by the 2007-2008 food price crisis that led to a shift in and the revisiting of their food stockpiling policies in the crisis aftermath.

\section{Key Findings}

Unless otherwise stated, all general findings are based on our fieldwork in Indonesia, the Philippines, and Malaysia. Our interviews suggested that following the 2007-2008 food price crisis there have been emerging views that complete reliance and dependence on trade and international markets for food is an unsafe option for most food importing governments, especially in the case of Indonesia, the Philippines, Malaysia, and India. There have been two separate but interlinked policy directions that have come to be seen as favorable in addressing future market uncertainties. The first is building up national stockpiles for essential staples and commodities; the second, despite its inefficiency, relates to governments pushing towards the goal of self-sufficiency, especially with respect to staple grains and key commodities. Table 2 shows some of the Asian countries that currently pursue emergency food reserve practices and the types of stocks they maintain.

There are emerging reports of governments adopting a self-sufficiency stance despite the economic and opportunity costs involved in pursuing such a strategy. Despite potential inefficiency, Indonesia, the Philippines, and Malaysia are currently pursuing policies and strategies geared towards more food self-sufficiency, especially in rice, and building up their buffer stocks. Emergency food reserve practices and policies are now seen as an integral part of the larger food policy and national risk management strategy of these countries.

Disasters and extreme climate events have been highlighted as additional justifications. Therefore, EFR emerges as a policy and/or practice where shared objectives of development (especially of food security) and disaster preparedness, including climate change adaptation, can be convincingly demonstrated by the respective governments.

Table 2 Selected Asian countries with existing food stockpiling policies and types of stocks maintained. Source Data derived from field findings by Lassa and Shrestha (2014), and Lassa et al. (2016)

\begin{tabular}{|c|c|c|c|c|c|}
\hline Entity & Country & Food security stockpiles & $\begin{array}{l}\text { Emergency/Humanitarian food } \\
\text { stocks }\end{array}$ & $\begin{array}{l}\text { Safety net food } \\
\text { stockpiles }\end{array}$ & $\begin{array}{l}\text { Food stockpile for export } \\
\text { purposes }\end{array}$ \\
\hline \multirow[t]{10}{*}{$\begin{array}{c}\text { Country } \\
\text { level }\end{array}$} & China & $\begin{array}{l}\text { Rice, wheat, corn, soya, } \\
\text { sugar }^{\mathrm{a}}\end{array}$ & & & \\
\hline & Japan & Rice, soybean, wheat & $\begin{array}{l}\text { Rice porridge, emergency food } \\
\text { supplies }\end{array}$ & & \\
\hline & India & Rice, wheat & Rice, wheat & Rice, wheat & Rice $^{\mathrm{a}}$ \\
\hline & Bangladesh & Rice & & & \\
\hline & Indonesia & Rice, frozen beef ${ }^{a}$ & Rice & Rice & \\
\hline & Philippines & Rice, corn, sugar & Rice & & $\operatorname{Corn}^{\mathrm{a}}$ \\
\hline & Malaysia & Rice & & & \\
\hline & Thailand & & & & Rice, cassava \\
\hline & Singapore & Rice & & & \\
\hline & Vietnam & Soybean $^{\mathrm{b}}$ & & & Rice \\
\hline \multirow{2}{*}{$\begin{array}{l}\text { Regional } \\
\text { level }\end{array}$} & APTERR & & Rice & & \\
\hline & SAARC & & Rice & & \\
\hline
\end{tabular}

APTERR = ASEAN Plus Three Emergency Rice Reserve; SAARC = South Asian Association for Regional Cooperation. Data on stockpiling are often treated as secret information. Therefore, most data are based on interviews

${ }^{\mathrm{a}}$ Listed not according to importance; ${ }^{\mathrm{b}}$ Not officially verified/validated 


\subsection{Food Stockpile Policy and Practices in Indonesia}

Indonesia has stockpiled rice for three main purposes: (1) to ensure adequate income for farmers; (2) to ensure an adequate stock of rice to control prices for ensuring adequate access for poorer consumers; and (3) to provide highly subsidized rice to the poorest in society as part of the government's Public Social Obligation (PSO) program. The agency in charge of public stockpiling is Badan Urusan Logistik (Bureau of Logistics) or BULOG, a stateowned company in charge of distribution, price control, and importing food commodities. The "rice for the poor" program, called RASKIN, has also been run by BULOG since 2005.

Due to the success in fulfilling its mandate to stockpile rice over the years since its inception, starting from the late 1980s BULOG was put in charge of handling and monitoring other commodities as well. This has included sugar, wheat, corn, soybeans, and soymeal, among others. The practice of public stockpiling of rice in Indonesia has been seen as a success and its contribution towards rice price stabilization, especially from the late 1960s to the 1980s, has been significant (Dawe 1995).

The reasons for public food stockpiling policies in Indonesia include: (1) increasing food production through the use of minimum procurement prices by the government; (2) increasing farmers' incomes; (3) ensuring the availability of sufficient food supplies/stocks for populations; (4) ensuring affordability and economic access of stockpiled food commodities; and (5) ensuring an adequate nutritional status of the people (particularly those living below the poverty line) (BULOG 2009).

In the context of 2007-2008, BULOG claimed to have successfully weathered the impact of the world food price crisis (Saifulah 2010). This was not because of any significant changes in the country's food policies but due to tweaks and adjustments made to them. First, BULOG strengthened its existing RASKIN program by increasing the number of beneficiaries from 10.8 million households in 2006 to 15.8 million households in 2007, 19.1 million households in 2008, and 18.5 million households in 2009. The 19.1 million households in 2008 were equivalent to almost 80 million people or about one-third of the total population of Indonesia (TN2PK 2015).

Second, the government augmented the rice stockpiles dedicated to dealing with emergency situations by increasing its procurement levels (Saifulah 2014, personal interview). These interventions were further boosted by good harvests during the 2007-2008 period, which meant there was less pressure to secure imports (Saifulah 2010, 2014, personal interview). It was also mentioned that there was less panic in the domestic rice market due to better information dissemination about Indonesia's food stocks.

\subsubsection{Food Stockpile Infrastructure and Logistics}

As of 2014, the Indonesian Bureau of Logistics had 1500 warehouses spread across 33 provinces. The total storing capacity today is about 4 million tons. BULOG does not yet have modern storage infrastructure like silos because they are not considered suitable for tropical climate conditions. Close to $90 \%$ of the stocks are dedicated to RASKIN. Upgrades (materials used, aeration technology, and integrated pest control) are happening in the warehouses to modernize facilities and reduce storage losses.

\subsubsection{Local Food Stockpiling}

One of the recent developments in policy has been the Ministry of Agriculture (MoA) Directive 2012, which was drafted together with the Ministry of Internal Affairs and the Ministry of Trade. According to this directive, local governments are encouraged to procure and maintain reserve stocks through their own means and at their own costs. This is seen as being in line with the existing Food Law (18/2012) that emphasizes the concept of shared responsibility between local and national governments in ensuring national food security.

Through the MoA, the central government provides special funds to the heads of local districts to be used at their discretion for the purposes of ensuring food security. These funds can be used for the building or maintenance of warehouses, the procurement of food, investment in local infrastructure, as well as the procurement and building up of a local district's own reserve stocks (Suryana 2014, personal interview). This directive was drafted in consultation with local governments across Indonesia.

The MoA has been encouraging production areas to stockpile a certain amount of rice as a strategic reserve (community reserve) at the local level (Suryana 2014, personal interview). Rice from this reserve can be "borrowed" by any member of the community when in need. A similar amount will have to be returned with an additional amount that is designated as a service charge or as interest. The actual amount is decided by the community.

\subsubsection{Food Stockpiling as a Strategy for Emergencies}

The Indonesian Bureau of Logistics maintains disaster management contingency stocks of 100 tons per district and 200 tons per province. These stocks can only be activated during an emergency. District stocks can be released upon the issuance of an official letter from the local Social Welfare Department. At least 56,000 tons of rice have been set aside for disasters across Indonesia. They are under the direct control of the central government and managed with the government's budget. The total government rice 


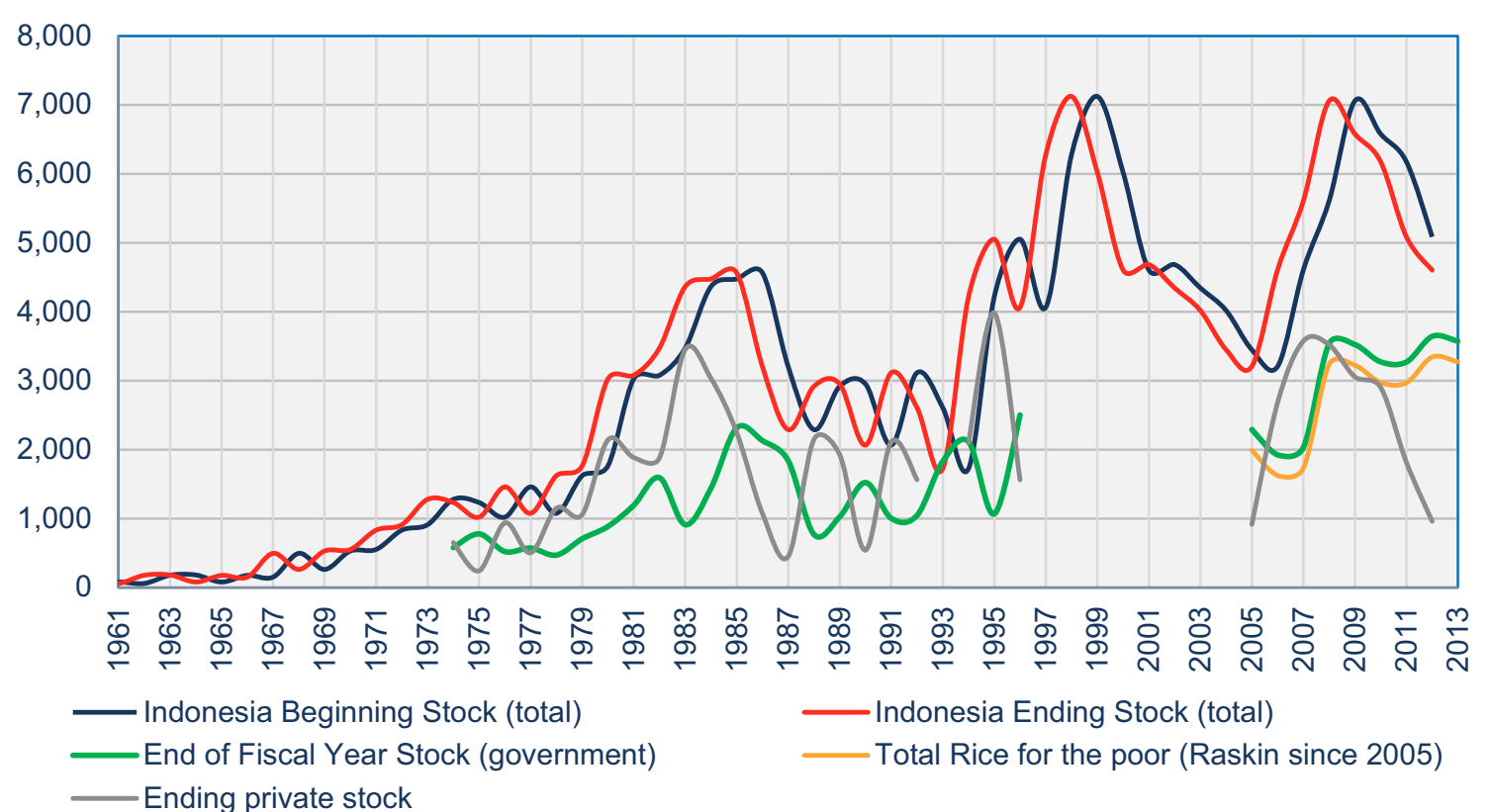

Fig. 1 Indonesia rice stockpiles (1000 tons), 1961-2013. Sources Data from BULOG (2014) (http://www.bulog.co.id/data_statistik. php), TN2PK (2015) (http://www.tnp2k.go.id/), and USDA (2014)

reserve is 300,000 tons, which are used for price stabilization and disaster response (this is separate from the RASKIN reserves-about three million tons a year during 2008-2013) (Saifulah 2014, personal interview). Given Indonesia's population of 264 million (2017), some argue (for example, Suryana 2014, personal interview) that this figure is too low and the ideal stock level should be closer to one million tons.

It is not easy to calculate the true stocks because there is no published data by the government of Indonesia. The estimation in Fig. 1 is based on the USDA's statistical data on rice stocks, including beginning and ending stocks, as well as private stocks. USDA's stock data are based on gross estimate between private and government stocks. Fortunately, published data from rice for the poor (RASKIN) have been recently made available (TN2PK 2015), which are also presented in Fig. 1. The total government stocks at BULOGg are the sum of RASKIN rice plus the emergency rice stocks (the annual allocation is 300,000 tons). The data in Fig. 1 are based on actual stocks.

\subsubsection{Future Food Stockpiling Under Changing Climate}

Stockpiling has been a strategy during climate shocks in colonial times Indonesia (Baum et al. 2015). Today, policymakers have argued that climate change and the resulting increasing uncertainty in production have been a concern for Indonesia's food security (Saifulah 2014, personal (https://www.ers.usda.gov/topics/crops/rice). Note: Since 2001, Fiscal year starts 1 January every year

interview). This view is also shared by Suryana (2014, personal interview) who argues that climate change and urban poverty are the greatest challenges for Indonesia:

We need to strengthen food reserve-ideal food reserve should be $20 \%$ of total demand ( 7.2 million tons). At the moment the food reserve at the community level and private stocks is 5 million tons while additional 2.2 million tons should be made available to stabilize the market. But if that additional 2 million tons is too costly then at least 1 million tons should be maintained as a rule of thumb (these figures exclude BULOG stock). (Suryana 2014, personal interview)

Some have also argued that climate is an important factor for future stockpiling and justifies the stockpiling policies but investments in dealing with climate shocks in the country are not in place (Dillon and Rantetana 2014, personal interview).

\subsection{Food Stockpiling Policy and Practices in the Philippines}

The National Food Authority (NFA) regulates the Philippine stockpiling policy. It falls under the auspices of the office of the President. Government agencies that sit on the NFA council include the Department of Agriculture (DoA), the Department of Finance, the Department of Trade and Industry, the National Economic Development Authority 
(NEDA), as well as representatives from the Central Bank. The NFA as an institution is present in all Philippine districts, which serve as both distribution and procurement centers. The NFA controls over 350 warehouses across the country, used primarily to store rice. The NFA sells its stocks to wholesalers in the respective districts and regions, who then retail the rice to consumers. The NFA is not involved in direct retail to end consumers (Panglinan 2014, personal interview).

\subsubsection{Rationale for Public Food Stockpiling and Its Mechanism}

There are numerous grounds under which public stockpiling of rice (primarily) has been justified and deemed necessary. Some of these include: (1) ensuring food security in the Philippines (in terms of availability and supply stability); (2) ensuring adequate access to food for the population (through market intervention and subsidizing rice); (3) guarding against seasonal supply disruptions (especially during the lean months July-September); (4) ensuring sufficient stocks to respond to emergency situations (natural hazard-induced disasters, for example typhoons); (5) boosting domestic production (through setting of a Minimum Support Price-producer subsidies); and (6) ensuring farmer incomes.

There are two distinctions made within the national food stock. The first, referred to as Emergency Stocks, is a 15-day supply of rice. This amounts to 31,640 tons (daily rice consumption rate of the Philippines) multiplied by a 15-day ration (Panglinan 2014, personal interview). This is the minimum amount that is maintained at all times. The second, referred to as the Strategic Rice Reserve, is used to shield against supply disruptions that are seasonal (Panglinan 2014, personal interview). The dry season during July-September, for example, corresponds to a low level of stocks in the market. For this reason, the NFA maintains a minimum of 30-day stocks $(30 \times 31,640$ tons $)$ from July 1-September 30 every year (Panglinan 2014, personal interview).

This 30-day buffer stock is inclusive of the 15-day emergency reserve. The NFA procures the necessary quantity for the 30-day buffer mostly through imports and this reserve is maintained and strategically located across the country by 1 July of each year. The trends of rice stockpiling by the NFA can be observed over the years (Fig. 2). Unfortunately, the seasonal stock pattern is relatively unclear. But it tends to accumulate starting in June/ July due to imports in anticipation of the lean months. February to April usually marks the low point of stocks in recent years. What is clearer is that in the recent presidential election years $(2016,2010$, and 1992) or a year after general election (1999 and 1986) the stock often peaked compared with the rest of the years.

Similar to rice, there is a cyclical pattern with regard to the stockpiling of corn in the Philippines. Production peaks in July to September, and the build-up of the NFA stocks tends to hit its highest level in October. This is largely to stop the prices from crashing in the local market. The NFA, however, maintains minimal levels of public corn stocks. Stockpiling of corn occurs intermittently, as the need arises to stabilize supply or prices in the domestic market.

\subsubsection{Recent Food Stockpiling Trends}

The Philippines food reserve data show a sudden rise in stockpiling after the food crisis in 2007-2008. It rose significantly in 2009 and peaked in 2010 (Fig. 2). Since 2010 the NFA has reduced its public food stock levels significantly. Even in the aftermath of the 2013 Haiyan/Yolanda Typhoon, which affected the country and its agriculture production severely, there was no sign of significant increases in public food stocks.

\subsubsection{Issues and Areas of Concern of the Current Food Stockpiling Program}

In the 1970s and 1980s, the NFA struggled to maintain its 30-day buffer stock largely because of a small procurement share from domestic production, and the insufficient and untimely arrival of rice imports. This situation does not seem to have changed much. Both recent and earlier studies have also highlighted the distorting effect of the NFA interventions in reducing the incentives for private traders to undertake purchasing, storage of stocks, and selling in the market (Sombilla et al. 2006).

The food security policy after the 2007-2008 food crisis was to achieve rice self-sufficiency by 2013 . The target, however, was not met in time and pushed back to 2016. In fact, food self-sufficiency is hard to be achieved. As of 2014, the self-sufficiency level for the Philippines stood around 94-95\% according to DoA and NEDA officials. According to NFA estimates it was somewhere around 87\% (Panglinan 2014, personal interview). A slight shift in the self-sufficiency policy, from $100 \%$ rice self-sufficiency towards $100 \%$ grain self-sufficiency (which would include corn, wheat, and other coarse grains that can be substitutes for rice), occurred during 2012-2013 (Lantican 2014, personal interview).

\subsubsection{Future Direction Under Changing Climate}

The future of stockpiling in the Philippines is going to be highly dependent on the results of the currently ongoing NFA internal review and audit (Panglinan 2014, personal 


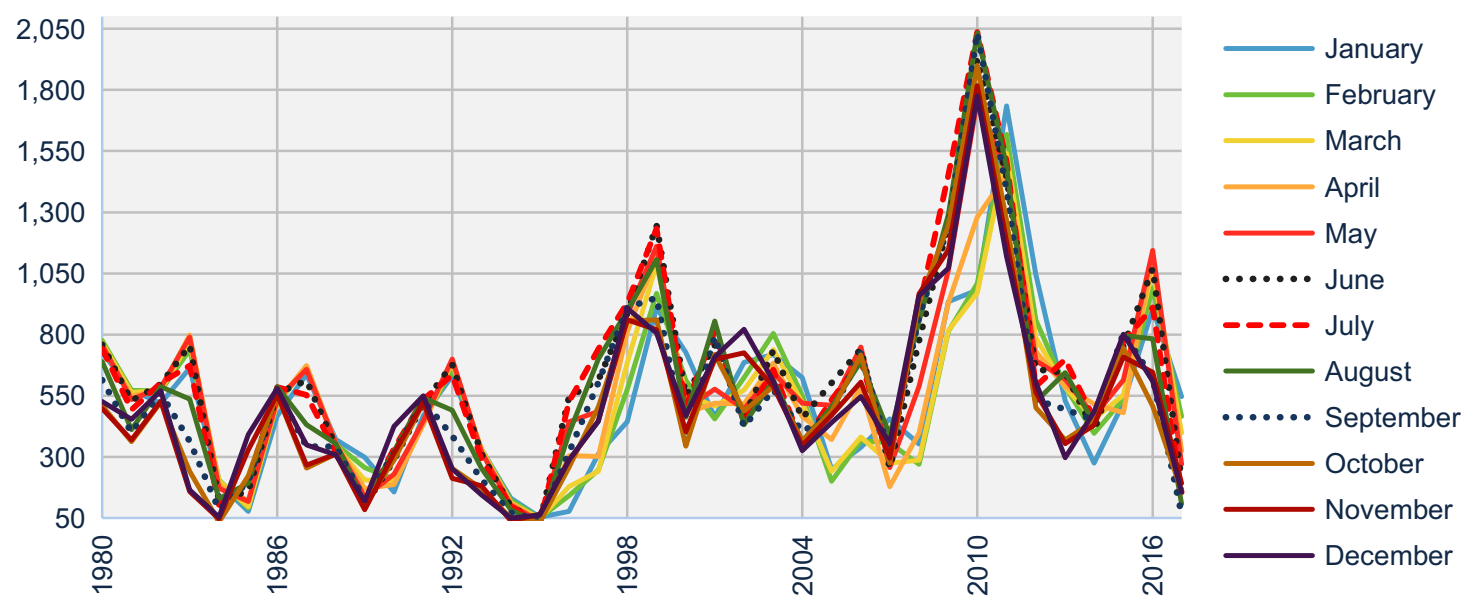

Fig. 2 Monthly rice stockpiles in the Philippines (1000 tons), 1980-2017. Source Data from NFA (2018) (http://www.nfa.gov.ph/about-us/2uncategorised/101-statistics)

interview). There seems to be wide consensus that some form of emergency stockpile is needed for the country given the growing number of weather-related and climate change impacts.

Up until today, stockpiling efforts have focused predominantly on rice (and to a much lesser degree on corn), there is a possibility that the government will start looking into other staple grains more seriously as they change their strategy from $100 \%$ rice self-sufficiency to food (staple grains) self-sufficiency.

A major justification for the stockpiling program has been ensuring access to rice for all in the Philippines. In this respect food stockpiling might also continue due to the high incidence of poverty that persists. With close to half of the population dependent on the agricultural sector, of which rice constitutes the bulk, a stockpiling program for farmer income and subsidy purposes is likely to remain politically important. Incomes from rice remain relatively low in the Philippines due to the high cost of seeds and other inputs (Lantican 2014, personal interview).

The Philippines heavily depends on food imports from the region-Thailand, Vietnam, and India. Any climatic incidents in the exporting countries will have immediate impacts on the Philippines' food stocks. Another change or development in stockpiling policies could be the disaggregation of emergency stocks, where other institutions, for example, the Department of Social Welfare, could directly control stocks for distribution during emergencies.

\subsection{Food Stockpiling Policy and Practices in Malaysia}

Malaysia has been a net importer of rice since the 1960s. Long-term rice stock data suggest that Malaysia has been trying to reduce its rice imports significantly over the last
30-40 years, since the end of the 1970s. Historically, Malaysia did not have a comparative advantage in terms of growing food. To some extent the legacy of colonialism to invest in and grow more commercial crops rather than food persisted even after independence in 1957. The El-Nino crisis in ASEAN as well as North America during 1973/74, which led to a global food crisis, was a major turning point in Malaysia with respect to food. Following that experience, there was greater government intervention in the market when the precursor to the Padiberas Nasional Berhad (BERNAS) was established and tasked to look into rice reserve (Arshad 2014, personal interview).

Malaysia has also improved its rice production, mainly through the increase of yields (for example, better seeds and technological inputs), while its rice land areas have been declining. Even though Malaysia realistically set its $65 \%$ self-sufficiency rate as an official target (Food Security Policy 2001-2010), the country still relies heavily on imports to meet the gap.

The country has increased its production since the early 1990s, which has allowed the government (through BERNAS, a semiprivate company in charge of rice in Malaysia) to increase its rice stocks through domestic procurement. During 2008, the government announced that BERNAS would significantly increase the size of the national buffer stock at any cost/price. In mid-January 2008 it was announced that the BERNAS rice stock levels would be increased from 92,000 million tons to 550,000 million tons, which in theory extended its reserve stocks from 14 to 90 days of consumption.

\subsubsection{Malaysia's Food Security Policy}

The most significant development in Malaysia after the 2007-2008 food price crisis was the development of the 


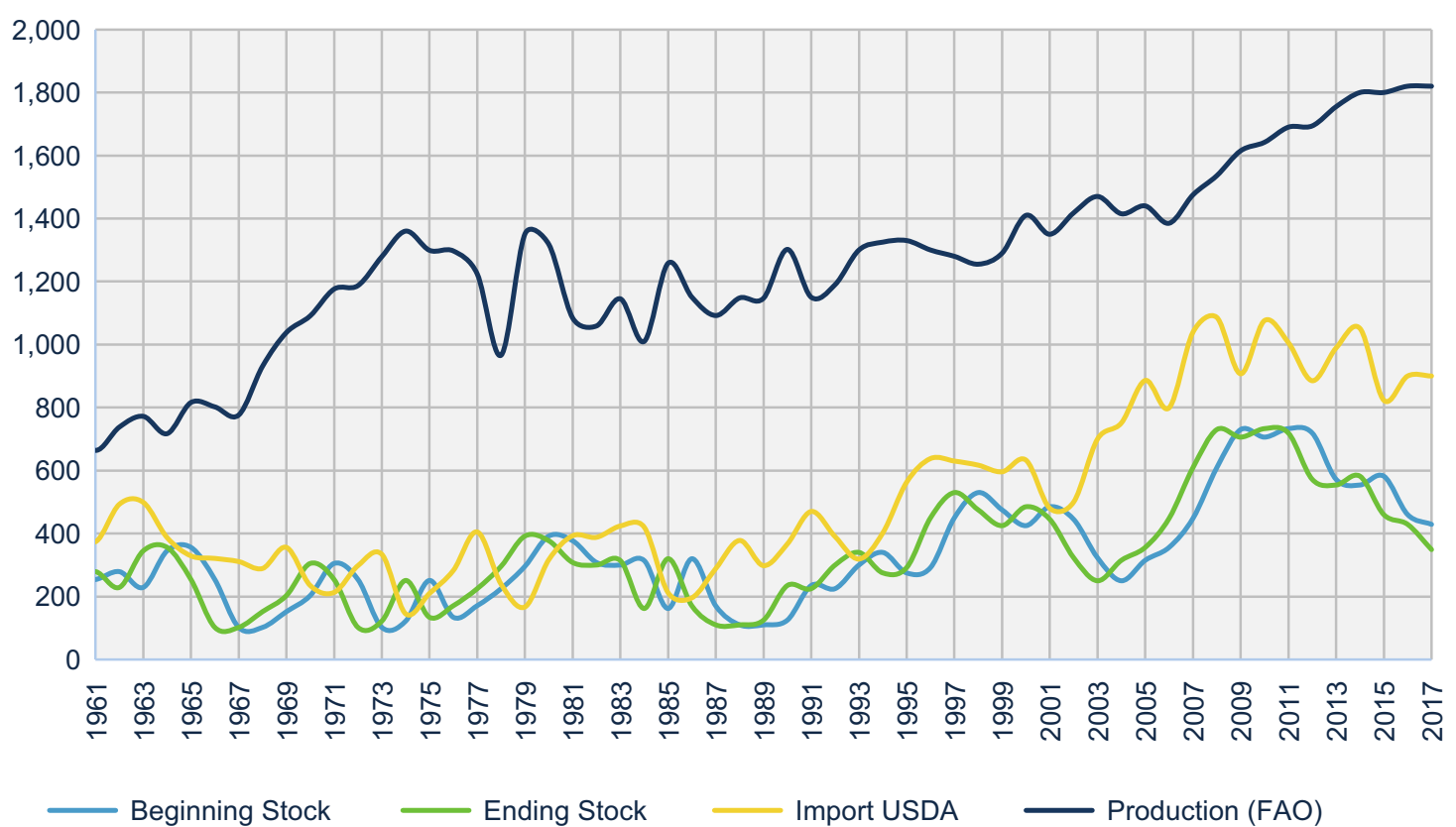

Fig. 3 Malaysia rice stocks (1000 tons), 1960-2017. Sources Data from FAO and USDA (2018) (http://ricestat.irri.org:8080/wrs2/entrypoint. htm)

Food Security Plan (FSP) in 2008. The FSP is a 10-year policy strategy that covers 2011-2020, a landmark development that addresses the issue of food security on a national level for the first time (Ghazali 2014, personal interview).

After the 2007-2008 food crises, BERNAS started to hold a 45-day supply of rice. While the need for an increase in production and a greater self-sufficiency level (SSL) for all food commodities was stressed by the government, there was no distinct or explicit move towards stockpiling any other food commodities. In terms of stockpiling/buffer stocks, Malaysia plans to stockpile a 4 months' supply of rice. The stocks would include BERNAS, private, and household stocks. The rationale for 4 months is based on the fact that one crop cycle is on average 3 months long, which would give authorities enough time to look for necessary back-up and secure stocks (Ghazali 2014, personal interview).

The FSP aims to boost production of all food commodities with a particular emphasis on rice. In Malaysia, food security is still essentially understood as rice security. The increase in the targeted SSL for rice closer to $70 \%$ was one of the points raised in the Food Security Plan. However, the real target according to some of the interviewees from the Ministry of Agriculture is $100 \%$. Malaysia is prepared to put in extra resources to achieve this goal as soon as possible. In 2014, 20,000 hectares were cleared in Sabah/Sarawak (Eastern Malaysia) for paddy cultivation. On average, the cost of planting one hectare of paddy, factoring in all input costs, is estimated at approximately USD 570 (RM 2400) (Salimi 2014, personal interview).

\subsubsection{Import Diversification}

Empirical data on annual rice stock in Malaysia suggests that Malaysia rice stock reached its peak during 2008-2012 (Fig. 3) and continued to decline since 2013. The stockpiling trend has been consistent with its import activities during 2008-2017. The experience of 2007-2008 was particularly scarring and difficult for Malaysia. Since then Malaysia has diversified its food import sources by importing rice from Vietnam, India, and Pakistan.

\subsubsection{Climate Change Consideration}

The FSP 2011-2020 did not take into account any aspects of climate change or its potential impacts for the future food security of Malaysia. There has been increasing focus on water issues, however, including changing precipitation patterns and extreme weather events, which have been flagged as potential risk factors for food production.

\section{Discussion}

Researchers have been asking the question whether emergency food reserves (EFR) can be counted as ways to deal with climate change (Briones et al. 2012). After decades of 
negotiations on regional grain reserves, a new model-the ASEAN Plus Three Emergency Rice Reserve (APTERR) - was agreed by the ASEAN member states, along with China, Japan, and South Korea in July 2012 (Briones et al. 2012). The primary objective of the APTERR is to ensure the availability and accessibility of rice during a regional food emergency, be it a supply shock, natural hazard-induced disaster, or price spike (Jeamchareon 2014, personal interview).

In the aftermath of the 2007-2008 crisis, the Agriculture Ministers of the G20 group of leading economies met and agreed on a proposal to reevaluate and establish a system of global humanitarian food stocks. Though the details have yet to be worked out in full, the plan is for a network of regional food reserves that operates using market principles and can be used only for emergency and humanitarian purposes (World Bank 2012). Today, the World Food Programme (WFP) is also coordinating the UN Humanitarian Response Depots (UNHRD) to maintain an international stockpile of food and other emergency resources. The UNHRD is a strategic stockpiling effort that oversees important emergency relief stocks, including medical kits, shelter items, and ready-to-use foods in Ghana, United Arab Emirates, Malaysia, Panama, Italy and Spain (WFP 2018).

Indonesia's and the Philippines' new policy framing for the need for EFR are based on two rationales: First, to safeguard against extreme weather events like droughts and typhoons and be able to have an emergency food stock should it be necessary; and second, to safeguard against the potential impact of climate on the production of stockpiled commodities and ensure the stability of domestic supply. The practice of food stockpiling is therefore likely to continue in some forms as long as countries perceive risks from climate variability.

However, it is still not clear how climate change helped Malaysia to justify their national rice reserve. Our research suggests that the selected Asian countries have been justifying an expansion of ERF policy in ways that are also contributing to the new addition of a basket of commodities that governments are keen on reserving. One justification is the erosion of trust in the international food markets and the long-term stability of international prices for key commodities. This, in particular, is the case for Malaysia and to some degree Indonesia.

Government obligations in providing food safety nets (for example, Indonesia's RASKIN program, and the Philippines' NFA-run subsidized food programs) are one of the reasons for maintaining EFR policy. There is also increasing evidence that various Asian governments, including Indonesia, the Philippines, and Malaysia, are adopting a self-sufficiency stance despite the economic and opportunity costs involved in pursuing such a strategy.
Public stockpiling of food in this case supports the overall policy direction by being an alternative mechanism to support subsidies and to defend floor prices and farmers' incomes.

Since 2012, potential distortions in international trade due to stockpiling practices have dominated discussions and debates at the WTO negotiations (Lassa and Shrestha 2014; Nakuja and Kerr 2018a). At issue is national stockpiling for food security, and its acceptability in the global trade regime. The issue of stockpiling for food security (anticipating climatic shocks or disasters) became the main contention that stalled the Trade Facilitation Agreement (TFA), after which a provision allowing some public stockpiling was accepted in 2014. This provisional acceptance of what has been referred to as the "peace clause" has made stockpiling an even more popular policy option for governments (Lassa and Shrestha 2014).

In the context of market globalization, EFR policy is prone to free-riding motives if it is used without proper justification. The notion of free-riding refers to the fact that EFR could be a camouflage as it is potentially used for trade instead of food security and humanitarian purposes. For disaster-prone archipelagic countries like Indonesia and the Philippines, disasters and climate change concerns have combined with lack of faith in the stability of international markets. Domestic food and agriculture policies have been the main justifications for public stockpiling of food, and most countries we visited also identified climate change as one of the factors that justify their stockpiling policies.

In pursuing public food stockpiling policies, governments have to be aware of the challenges and domestic implications of such policies and adopt a system that allows for effective monitoring and governance of food stocks. Without proper justification, EFR can be toxic to the international food market. However, food security imperatives require governments and humanitarian actors to ensure a minimum physical emergency grain reserve for humanitarian purposes and these should be seen as investments in the public good (von Braun 2009).

\section{Conclusion}

Climate change impacts food producers and food importers differently. Indonesia, the Philippines, and Malaysia are net importers of rice and other foods. In the context of climate change, one needs to understand the long-term implications of food prices and food trade. While ASEAN through AFSIS has been able to regularly update food information systems, including losses from floods and droughts, a new approach to monitoring systems is necessary. Thus EFR/ EFS is one of the options for disaster preparedness, 
including climate change adaptation. While it is clear that Indonesia, the Philippines, and Malaysia have been readopting EFR policy in recent years, one key question for further research is whether this option can be justified when measured by both efficiency and effectiveness in the long run.

Acknowledgements This research was supported and funded by the S. Rajaratnam School of International Studies (RSIS) Singapore during 2013-2015. Earlier drafts of the paper were presented at the 60th Annual Conference of the Australian Agricultural and Resource Economics Society, Canberra, 4 February 2016 and as a working paper and policy brief at the Centre for Non-Traditional Security Studies (Caballero et al. 2016, NTS Report No. 3).

Open Access This article is distributed under the terms of the Creative Commons Attribution 4.0 International License (http://crea tivecommons.org/licenses/by/4.0/), which permits unrestricted use, distribution, and reproduction in any medium, provided you give appropriate credit to the original author(s) and the source, provide a link to the Creative Commons license, and indicate if changes were made.

\section{References}

AFSIS (ASEAN Food Security Information System). 2017. The ASEAN plus three food security information system. http://www. aptfsis.org/aboutUs. Accessed 30 Nov 2017.

APTERR (ASEAN Plus Three Emergency Rice Reserve). 2017. ASEAN plus three emergency rice reserve. http://www.apterr. org/what-is-apterr. Accessed 30 Nov 2018.

ASEAN (Association of Southeast Asian Nations). 1979. Agreement on the ASEAN food security reserve. New York, 4 October 1979.

Baum, S.D., D.C. Dankenberger, J.M. Pearce, A. Robock, and R. Winkler. 2015. Resilience to global food supply catastrophes. Environment Systems and Decisions 35(2): 301-313.

Bigman, D., and S. Reutlinger. 1979. Food price and supply stabilization: National buffer stocks and trade policies. American Journal of Agricultural Economics 61(4): 159-163.

Brennan, D. 2003. Price dynamics in the Bangladesh rice market: Implications for public intervention. Agricultural Economics 29(1): 15-25.

Briones, R.M., A. Durand-Morat, E.J. Wailes, and E.C. Chavez. 2012. Climate change and price volatility: Can we count on the ASEAN plus three emergency rice reserve? ADB Sustainable development working paper series no. 24. Manila: Asian Development Bank.

Brolley, M. 2015. Al Schmidley: Rice security is food security for much of the world. Rice Today, 6 October 2015. http://ricetoday. irri.org/al-schmidley-rice-security-is-food-security-for-much-ofthe-world/. Accessed 29 Nov 2018.

BULOG (Bureau of Logistics). 2009. The role of rice reserve agency in strengthening national and regional food security. In Presentation at the ASEAN regional workshop, 8 May 2009, Jakarta, Indonesia.

Caballero-Anthony, M., P. Teng, J. Lassa, T. Nair, and M. Shrestha. 2016. Public stockpiling of rice in Asia Pacific. NTS report No. 3, April 2016. Singapore: S. Rajaratnam School of International Studies, Nanyang Technological University. https://www.rsis. edu.sg/wp-content/uploads/2016/04/NTS-Report-No-3-11April2016. pdf. Accessed 29 Nov 2018.
Caballero-Anthony, M., P.S. Teng, M. Shrestha, T. Nair, and J.A. Lassa. 2015. Public stockpiling and food security. Policy Brief, May 2015. Singapore: S. Rajaratnam School of International Studies, Nanyang Technological University. https://www.rsis. edu.sg/wp-content/uploads/2015/06/PB150603_Public-Stockpil ing.pdf. Accessed 29 Nov 2018.

Dawe, D. 1995. The Macroeconomic benefits of stabilizing food prices. The Indonesian Food Journal 5(10): 43-64.

Dawe, D., and T. Slayton. 2010. The word rice market crisis of 2007-2008. In The rice crisis: Markets, policies and food security, ed. D. Dawe, 15-28. Rome and Washington, DC: FAO and Earthscan.

Dorosh, P.A. 2009. Price stabilization, international trade and national cereal stocks: World price shocks and policy response in South Asia. Food Security 1(2): 137-149.

Fan, S., and J. Brzeska. 2014. Building a resilient global food system by lowering food price spikes and volatility. In Conference Brief 16. Building resilience for food and nutrition security 2020, 17-19 May 2014, Addis Ababa, Ethiopia. https://reliefweb.int/ sites/reliefweb.int/files/resources/2020resilienceconfbr16.pdf. Accessed 30 Nov 2017.

FAO (Food and Agriculture Organization of the United Nations). 2003. Trade reforms and food security: Conceptualizing the linkages. Rome: FAO.

Federal Civil Defense Administrator. 1952. Home food reserves for emergency use. The American Journal of Nursing 52(1): 54.

Gardner, B.L. 1979. Optimal stockpiling of grain. Toronto: Lexington.

Gilbert, C.L. 2011. Food reserves in developing countries: Trade policy options for improved food security. Issue paper no. 37. Geneva: International Centre for Trade and Sustainable Development.

Hadley, D.D., and S. Fan. 2010. Reflections on the global food crisis: How did it happen? How has it hurt? And how can we prevent the next one? Washington, DC: International Food Policy Research Institute.

Hawkes, N. 1974. World food conference: Amid politicking, some progress. Science 186 (4167): 905-908.

Hossain, M., and U. Deb. 2010.Volatility in rice prices and policy responses in Bangladesh. In The rice crisis: Markets, policies and food security, ed. D. Dawe, 92-108. Rome and Washington, DC: FAO and Earthscan.

Lassa, J.A., and M. Shrestha. 2014. WTO breakthrough on stockpiles: Sustaining food security. Commentary No. 245. Singapore: S. Rajaratnam School of International Studies, Nanyang Technological University. https://www.rsis.edu.sg/rsis-publication/nts/ co14245-wto-breakthrough-on-stockpiles-sustaining-food-security/ \#.W_XDnWzQZPY. Accessed 29 Nov 2018.

Lassa, J., A. Lai, and T. Goh. 2016. Climate extremes: An observation and projection of its impacts on food production in ASEAN. Natural Hazard 84(S1): 19-33.

Massell, B.F. 1969. Price stabilization and welfare. Quarterly Journal of Economics 83(2): 284-298.

Nakuja, T., and W.A. Kerr. 2018a. Do WTO commitments restrict the policy space of countries wishing to provide food security through stockholding programs? Journal of World Trade 52(6): 967-993.

Nakuja, T., and W.A. Kerr. 2018b. Food security though public stockholdings and trade distortions. British Food Journal 120(5): 1089-1105.

Nozue, M., K. Ishikawa-Takata, N. Sarukura, K. Sako, and N. Tsuboyama-Kasaoka. 2014. Stockpiles and food availability in feeding facilities after the Great East Japan Earthquake. Asia Pacific Journal of Clinical Nutrition 23(2): 321-330. 
Orford, A. 2015. Food security, free trade and the battle for the state. Journal of International Law and International Relations 11(2): $1-67$.

Porter, R.S. 1950. Buffer stocks and economic stability. Oxford Economic Papers, New Series 2(1): 95-118.

Porter, J.R., L. Xie, A.J. Challinor, K. Cochrane, S.M. Howden, M.M. Iqbal, D.B. Lobell, and M.I. Travasso. 2014. Food security and food production systems. In Climate change 2014: Impacts, adaptation, and vulnerability. Part A: Global and sectoral aspects. Contribution of working group II to the fifth assessment report of the Intergovernmental Panel on Climate Change, ed. CB. Field, V.R. Barros, D.J. Dokken, K.J. Mach, M.D. Mastrandrea, T.E. Bilir, M. Chatterjee, K.L. Ebi, et al., 485-533. Cambridge: Cambridge University Press.

Saifulah, A. 2010. Indonesia's rice policy and price stabilization programme: Managing domestic prices during the 2008 crisis. In The rice crisis: Markets, policies and food security, ed. D. Dawe, 109-122. Rome and Washington, DC: FAO and Earthscan.

Saini, S., and A. Gulati. 2016. India's food security policies in the wake of global food price volatility. In Food price volatility and its implications for food security and policy, ed. M. Kalkuhl, J. von Braun, and M. Torero, 331-352. Berlin: Springer.

Sen, A. 1981. Poverty and famines: An essay of entitlement and deprivation. Oxford: Clarendon Press.

Sombilla, M.A., F.A. Lantican, and J.C. Beltran. 2006. Marketing and distribution in Balisacan. In Securing rice, reducing poverty: Challenges and policy directions, ed. M.A. Balisacan and Associates, 213-238. Southeast Asian Regional Center for Graduate Study and Resarch in Agriculture, Los Banos, Laguna, Philippines.

Teng, P., M. Caballero-Anthony, and J.A. Lassa. 2016. The future of rice security under climate change. NTS report No. 4, July 2016. Singapore: S. Rajaratnam School of International Studies, Nanyang Technological University. https://www.rsis.edu.sg/wpcontent/uploads/2016/10/NTS-Report4-July2016-ClimateChange AndRice.pdf. Accessed 29 Nov 2018.

Timmer, P.C. 1975. The political economy of rice in Asia: Indonesia. Food Research Institute Studies 14(3): 197-231.

Timmer, P.C. 2010. Reflections on food crises past. Food Policy 35(1): $1-11$.

TN2PK (National Team for the Acceleration of Poverty Reduction). 2015. RASKIN: The challenge of improving programme effectiveness. Office of the Vice President of the Republic of Indonesia. http://www.tnp2k.go.id/images/uploads/downloads/ TNP2K\%20Report\%20Raskin\%20the $\% 20$ challenge $\% 20$ of $\% 20$ improving\%20programme\%20effectiveness.pdf. Accessed 29 Nov 2018.

von Braun, J. 2009. Addressing the food crisis: Governance, market functioning, and investment in public goods. Food Security 1(1): $9-15$.
$\mathrm{Vu}, \mathrm{T}$. 2003. Of rice and revolution: The politics of provisioning and state-society relations on Java, 1945-49. South East Asia Research 11(3): 237-267.

Welton, G. 2011. The impact of Russia's 2011 grain export ban. Oxfam research report 28 June 2011. https://www.oxfam.org/ sites/www.oxfam.org/files/rr-impact-russias-grain-export-ban280611-en.pdf. Accessed 30 Apr 2018.

World Bank. 2012. Using public food grain stocks to enhance food security. Washington, DC: World Bank.

WFP (World Food Program). 2018. UN humanitarian response depot. http://www1.wfp.org/unhrd. Accessed 29 Nov 2018.

Wright, B., and C. Cafiero. 2011. Grain reserves and food security in the Middle East and North Africa. Food Security 3(1): S61-S71.

\section{List of Personal Interviews}

Arshad, F.M. (Director). 2014. Personal interview with M. Shrestha, Institute of Agricultural and Food Policy Studies, University Putra Malaysia (UPM), Malaysia, 23 September 2014.

Dillon, H.S., and M. Rantetana (Chief and advisor). 2014. Personal discussion with J.A. Lassa and M. Shrestha, Office of the Presidential Special Envoy for Poverty Reduction, Jakarta, Indonesia, 8 September 2014.

Ghazali (Lecturer). 2014. Personal interview with M. Shrestha, Institute for Environment and Development (LESTARI), National University of Malaysia (UKM), Malaysia, 22 September 2014.

Jeamchareon, M. (Director). 2014. Personal interview with J.A. Lassa, ASEAN Food Security Information System (AFSIS) Office, Bangkok, Thailand, 13 August 2014.

Lantican, F.A. (Professor). 2014. Personal interview with J.A. Lassa and M. Shrestha, University of the Philippines Los Banos, the Philippines, 18 September 2014.

Panglinan, F. (Chairperson). 2014. Personal interview with J.A. Lassa and M. Shrestha, National Food Authority, Quezon City, Manila, 14 November 2014.

Saifulah, A. (Senior staff). 2014. Personal interview with J.A. Lassa and M. Shrestha, Bureau of Logistics (BULOG) Office, Jakarta, Indonesia, 10 September 2014.

Salimi, M.B.S. (Senior staff). 2014. Personal interview with M. Shrestha, Strategic Planning and International Division, Ministry of Agriculture, Kuala Lumpur, Malaysia, 24 September 2014.

Saengbangka, W. (Executive director). 2014. Personal interview with J.A. Lassa, ASEAN Plus Three Emergency Rice Reserve (APTERR) Secretariat, Bangkok, Thailand, 13 September 2014.

Suryana, A. (Senior researcher). 2014. Personal interview with J.A. Lassa and M. Shrestha, Minister of Agriculture, Bogor Office, Indonesia, 11 September 2014. 